предметом пристального внимания казахстанских ученых, специалистов и руководителей как коммерческих организаций, так и органов исполнительной власти всех уровней государственной власти. Причиной этого является глобальное признание проектного менеджмента как современной философии эффективного и результативного менеджмента.

Ключевые слова: государственное управление, управление проектами, административная реформа, менеджмент, государство.

IRSTI 06.73

UDC 338.001

https://doi.org/10.51579/1563-2415.2021-1.20

\title{
MUNICIPAL INFRASTRUCTURE PROJECT IN THE DEVELOPMENT OF INFRASTRUCTURE IN KAZAKHSTAN
}

\author{
I.Y. Khan* ${ }^{1}$, A.B. Abylkasym ${ }^{2}$, A.J. Kurmantayeva ${ }^{3}$, A.R. Shalbayeva
}

${ }^{1}$ Miras University, Shymkent, Kazakhstan

${ }^{2}$ Shymkent University, Shymkent, Kazakhstan

${ }^{3}$ KazNPU named after Abay, Almaty city, Kazakhstan

${ }^{4}$ International humanitarian and technical University, Shymkent, Kazakhstan

e-mail:musik711@mail.ru

Annotation. The study focuses on the financing of infrastructure projects using municipal bonds.

Originality of the research. The article considers a set of measures designed to activate the process of attracting investment in infrastructure at the municipal level using bonds. The parameters of securities issues of concessionaires were studied, and the experience of managing municipalities with securities as an element of debt policy was analyzed.

Research result. The results of the research can be useful both in developing the financial policy of the state management of spatial development at the national and regional levels, and in conducting further research on the activation of the investment process in Kazakhstan at the municipal level.

Key words: municipal bonds, infrastructure, projects, activation, management.

Basic provisions. The achievement of outstripping growth in the competitiveness of the regional economy as a result of the use of municipal infrastructure projects, which contributes to the emergence of synergistic and multiplicative effects, in comparison with the use of investments, is justified. For the first time, the authors propose an algorithm for methodological justification of the effectiveness of the use of municipal infrastructure projects in order to increase the competitiveness of the regional economy and decisions on the feasibility of using municipal infrastructure projects.

Introduction. One of the key features that has historically been critical for our country is the significant heterogeneity of territorial development.

The combination of geographical, economic, socio-demographic factors creates a certain imbalance in the spatial development of the Republic of Kazakhstan, which has been repeatedly noted by Kazakh scientists as an obstacle to the sustainable growth of the country's economy.

Of course, there is a similar imbalance in other countries [1].

But modern experience, including foreign experience, shows that the already established model of simple redistribution of part of income between unevenly developing regions of the country through the mechanism of the budget process is losing its effectiveness [2,3]. In the process of such redistribution between the donor and recipient regions, the prerequisites for intensive economic growth of the latter are not formed.

The main task in this case should be the mechanism of not just redistribution, but the intensification of economic processes, which is a direct consequence of creating conditions that are attractive for life. A key factor in the decision is the qualitative growth of investment in the region's infrastructure.

Materials and methods. The problem of municipal infrastructure deficit (taking into account the territorial conditions of Kazakhstan, especially its length and spatial disproportionality) is of particular importance.

Until recently, only current or average repairs of road networks and infrastructure facilities were carried out in this area, which did not affect the improvement of the living environment.

In turn, the coordinated and progressive development of municipal infrastructure not only contributes to the retention of the local population, but also increases the investment and migration attractiveness of the territories.

Results and discussion. The acute urgency of the problem of state competitiveness clearly indicates the need to strengthen territorial connectivity. However, the practical result of this strategy does not involve the renovation of municipal infrastructure, although the infrastructure library scheme is most preferable for municipalities $[4,5]$. At the 
same time, the sanctions costs, risks and unattractiveness of domestic investment, as well as the pathological restraint of entrepreneurs and the fear of the population have led to the fact that money is «dead weight» on the accounts.

Municipal infrastructure bonds can become an effective tool for attracting private investment and at the same time for real development (including the first mortgage loan) [6]. They are widely used all over the world for housing renovation projects, development of engineering and transport infrastructure, modernization of housing and utilities and construction of social facilities, and in the case of depressed areas or single - industry towns-for complex rehabilitation or evolution of settlement functions.

For example, in the US, infrastructure bonds are issued by municipalities as «special purpose bonds». Revenue bonds are issued for specific infrastructure projects that generate cash flow [7]. If the object of the issue is a project in the field of education, medicine or social purposes, General bonds are issued. Important detail: in the United States, income from municipal infrastructure bonds in most States is not taxed, which creates additional investment attractiveness [8].

In this regard, the authority of the works of such American researchers as Stephen Erie, Brett Frischmann, and Robert Stimson is indisputable.

We should also note the influence of publications by Bank of America/Merrill Lynch and Brookings Institution, Barbara Weber and Andrew ang. Periodicals of the National Association of U.S. counties and the U.S. [9] Congress provided important assistance to the development of the municipal bond market. As a result, in 2016, the total issue of us municipal bonds reached almost $\$ 4$ trillion [10]. This experience is significant, since in different socioeconomic systems, the interaction of internal processes with external conditions and internal opportunities is a determining factor in the qualitative change of space and the environment of life. The functioning of society is primarily related to the interests of both citizens and the state. And the consequence of the realization of these interests is the following: will there be a balance of power on a specific problem in society as a whole or not.

Currently, the use of best practices in the renovation of the infrastructure of municipalities in Kazakhstan is constrained by the willingness of municipalities themselves to organize activities to attract investment. The main constraints to improving the investment image of a municipality (MP) include the following:

- insufficient relevance or lack of investment aspects of municipal development plans, non-compliance with the requirements of financial structures, low level of interconnection of municipal development plans with regional and Federal strategic development;

- inconsistency of investment plans of MP with industry development plans (energy, roads, etc.) and insufficient financial capacity of municipalities to pay for the development of infrastructure development plans by specialized companies and a possible first mortgage payment;

- lack of experienced full-time specialists to organize the issue and effective management.

In modern Kazakhstan conditions, it is possible to consider three types of municipal infrastructure bonds: program, General and project (mortgage). The first type is program bonds that Finance the development of programs and infrastructure development plans for the Ministry of defense.

This kind of essential to release those municipalities that do not have infrastructure development plans that define the «growth points» of MP, taking into account the institutional features of the region and the requirements of investment structures. plans for the Ministry is based on the technical inspection of the infrastructure of the MP tariff audit of the housing and may include:

- documents of territorial planning and urban zoning (justification of the need to make changes to them);

- development of infrastructure schemes for settlements and industrial facilities;

- coordination of schemes for long-term investment development of municipalities with schemes for longterm (8-12 years) development of regional electric and gas supply organizations;

- recommendations for forming a long-term tariff.

This type of bond can be redeemed either from the General tax revenues of the municipality, or from the income from completed projects, according to plans for the Ministry of defense, or from the proceeds from the sale of such projects.

The second type is General bonds, which are respectively repaid from the total revenue base of the municipality. They are issued to Finance non-profit projects: repair of General-purpose roads, improvement of squares and parks, construction of kindergartens and schools, etc [11].

In turn, project (income), or mortgage bonds (the third and most promising type) issued for co-financing projects of municipal-private partnership (MPP), which are provided with stable demand (small generation, housing and utilities, rental housing, etc.). the source of repayment funds is income from the project or its sale.

Municipal infrastructure bonds could become a real tool for attracting private investment and simultaneously municipal development (including the first mortgage payment). They are widely used in Western countries for housing renovation projects, development of engineering and transport infrastructure, modernization of housing and utilities and construction of social facilities, and in the case of depressed areas or single - industry towns-for complex rehabilitation or evolution of the functions of single-industry settlements. 
In the US, infrastructure bonds are issued by municipalities as «special purpose bonds». Revenue bonds are issued for specific infrastructure projects that generate cash flow. If the object of the issue is a project in the field of education, medicine or social purposes, General bonds are issued. Important detail: in the United States, income from municipal infrastructure bonds in most States is not taxed, which creates additional investment attractiveness. In 2018 the total issue of us municipal bonds amounted to almost $\$ 4$ trillion, or about $10 \%$ of the total amount of debt on the bonds. In another Federal state, Canada, municipal infrastructure loans are regulated by provincial laws. Accordingly, any issue of a municipality must be authorized by a specific province.

In modern Kazakhstan conditions, the most promising is project (income) or mortgage bonds issued for cofinancing projects of municipal-private partnership, which are provided with stable demand (small generation, housing and utilities, rental housing, etc.). the source of repayment funds is income from the project or its sale. For the first installment of an infrastructure mortgage (up to $20-30 \%$ of the project cost), the issue of targeted mortgage bonds can be arranged.

But in an infrastructure mortgage scheme, it is very important to balance the interests of investors and infrastructure users, so that an increase in payment amounts or an increase in tax deductions does not become excessively burdensome.

In addition, for real control of the sources of repayment of bonds-project revenues-a Republican financial institution is needed, independent of regional and municipal authorities, which would conduct expertise and audit of projects and accumulate all the income that the infrastructure project will generate in order to pay investors according to the register.

An example of such an institution is the German development Bank KfW (development Bank of the Federal Republic of Germany), founded in November 1948 as a credit Institute for economic recovery. Owners: 80\% - the Federation, 20\% - Federal lands, assets-over 500 billion euros. KfW's mission is to provide long-term loans to Federal programs of structural transformation in the economy and control their intended use. Financing of the Bank's activities is based on the issue of bond loans in accordance with the law on KfW. Due to the subsidiary responsibility of the state, such bonds have a high investment rating (AAA/Aaa/AAA), which allows the Bank to attract significant loans for a long time and on the terms necessary for implementing special programs to support small and medium-sized businesses in the construction and rehabilitation of housing, as well as financing municipal infrastructure.

The main restriction for issuing municipal bonds in Kazakhstan is contained in the Budget code. Despite the absence of an explicit ban on issuing municipal bonds for infrastructure projects, this legislative incident is identified by both regulators and market participants as a current ban. Conflict of bonds: they are either project - basedinfrastructure, but not municipal, or-municipal, but not infrastructure.

Moreover, the recently adopted new Budget code, which was approved by the government on improving the efficiency of public Finance management and passed the procedure of public hearings, practically repeated the previous version in terms of the content of the municipal bonds section.

If changes are made to the Budget code regarding the types, regulations for organizing and conducting targeted municipal bond loans to Finance the development of municipal infrastructure, as well as the creation of a management structure - the infrastructure development Bank-there will be a legislative framework and a legitimate real institution that coordinates infrastructure development projects.

This will allow municipalities to independently attract financial resources directly from the financial market without state subsidies. As a result, a self-regulating mechanism will be formed aimed at increasing the income of municipalities, solving social problems and developing the country's investment potential.

However, this table does not reflect the problems of development of the market of bonds issued to Finance concessions, which the professional community has repeatedly informed the regulator - the national Bank of the Republic of Kazakhstan, as well as industry ministries and departments involved in the practice of PPP implementation. Let's describe them in more detail.

First, the issue of preparation of the legislative and regulatory framework for the intensification of the process of attracting investment capital in the framework of PPP is quite acute.

Moreover, the issues of legal regulation of both investments in infrastructure projects and the activities of the projects themselves need to be worked out, especially the duality of the legal status of bonds: the issue is allowed, but the specific conditions for issue and circulation are not established.

Secondly, despite the fact that some experience has already been accumulated and the regulatory framework for the implementation of PPP projects has been developed, there is still uncertainty in the process of regulation and control within the framework of monitoring the implementation of relevant legislative acts. Not for the first time, it is noted that there is still no state body that could lead2 changes in the regulation of concession bonds. Its mission is to timely monitor changes in the legal field, market fluctuations, investor sentiment, and other criteria and factors that directly affect the interaction between private capital and the state. It is useful to study successful foreign experience, for example, the Hangzhou action Plan. 
Third, within the framework of creating mutually beneficial and transparent, understandable conditions for PPP, the issue of forming guarantees from the state in the field of ensuring the return on investment in concession bonds remains open. tee of Kazakhstan.

Unlike bonds of national concessions, loans for regional projects are usually not provided with a state guaran-

Fourth, special attention should be paid to the relative limitations of the number of stakeholders involved in the financing of PPP projects. Moreover, this problem concerns both established investors who have been operating for a long time, and potential ones. But the specifics of investment in infrastructure projects create conditions in which only institutional investors are real. At the same time, a significant part of such investors are not involved, for example, pension assets and NPF investments are rarely used.

\section{References}

1. Nurasheva K.K., Mergenbayeva A.T., Kulanova D.A., Abdikerimova G.I. (2019) et al. IPO Market: Transformation of Savings into Investments, Bulletin of National Academy of Sciences of the Republic of Kazakhstan, vol. 1, No. 377, pp. 119-125

2. Kilp J., Anvari V., Springfield S., Roberts C. (2019) The Impact of the Global Financial Safety Net on Emerging Market Bond Spreads, Russian Journal of Money and Finance, vol. 78, No. 2, pp. 43-66

3. Khamidullina E.R. (2013) The stages of development of the legislation on the securities market in Kazakhstan, Vestnik KazNU, Ser. Yuridicheskaya, No. 3, pp. 118-123. (In Russ.)

4. K.O. Shayakhmetova, A.T. Uteubaeva, A.A. Kabiev, B.T. Nazhmidenov (2019) Conceptual essence of risks in the financial market, $N$ e w s of the national academy of sciences of the republic of kazakhstan series of social and human sciences ISSN 2224-5294, Volume 3, No. 325, pp. 284-294.

5. L.M. Sembiyeva, A.A. Orozonova (2019), Strategy and tactics of financial policy of kazakhstan in the conditions of development of integration processes, News of the National academy of sciences of the Republic of Kazakhstan, Series of agricultural sciences, ISSN 1991-3494, 2019, Vol. 5, No. 381, pp. 24-30.

6. Oficial'nyj sajt Kazahstanskoj fondovoj birzhi (KASE) (Official website of the Kazakhstan Stock Exchange (KASE)). http://old.kase.kz /

7. http://kase.kz/ru/news/show/89487/) http://kase.kz/ru/tickers/

8. Pravila osýestvlenı1a depozitarno1 1 inoı deıatelnostı v otnoshenı mýnıtsipalnyh obligatsı (The rules of the charges of the Depositary and other activities in relation to municipal bonds), Ýtverjdeno resheniem Soveta direktorov $A O$ «Tsentralnyl depozıtarı tsennyh býmag» 16.07.2010g., Pvedeny V deıstvie s 01.01 .2019 g. http://www.kacd.kz/download/policyl/rules

9. Kilp J., Anvari V., Springfield S., Roberts C. (2019) The Impact of the Global Financial Safety Net on Emerging Market Bond Spreads, Russian Journal of Money and Finance, M., tom 78, No. 2, pp. 43-66.

10. AIFC Regulation on Obligations. December 20, 2017, Astana, Astana International Finance Centre.

11. Zakon Respubliki Kazahstan ot 2 ijulja 2003 goda No. 461-II O rynke cennyh bumag (s izmenenijami i dopolnenijami po sostojaniju na 05.10.2018 g.) (Law of the Republic of Kazakhstan No. 461-II of July 2, 2003 on the Securities Market (as amended as of 05.10.2018)).

\section{ҚАЗАКСТАННЫН ИНФРАҚҰРЫЛЫМЫН ДАМЫТУДАҒЫ МУНИЦИПАЛДЫК ИНФРАҚҰРЫЛЫМДЫК ЖОБА И.Ю. Хан ${ }^{1}$, А.Б.Әбілқасым ${ }^{2}$, А.Ж.Курмантаева ${ }^{3}$, А.Р. Налбаева ${ }^{4}$ \\ ${ }^{l}$ Мирас университеті, Шымкент, Қазақстан \\ ${ }^{2}$ Шымкент университеті, Шымкент, Қазақстан \\ ${ }_{3}^{3}$ Абай атындавы ҚазҰПУ, Алматы, Қазақстан \\ ${ }^{4}$ Халықаралық гуманитарлық-техникалық университеті, Шымкент, Қазақстан e-mail: musik711@mail.ru}

Түйін. Бұл зерттеу, мунищипалды облигачияларды пайдалану арқылы инфрақұрылымдық жобаларды қаржыландырува арналван.

Зерттеудін бірегейлігі. Мақалада облигачияларды қолдана отырып, муниџипалитеттер дензейінде инфрақұрылымzа инвестициялар тарту прочесін күшейтуге арналван шаралар кешені қарастырылван. Кониессионерлердің бавалы қаваздарын шыгару параметрлері зерттелді, муничипалитеттерді борыштық саясаттың элементі ретінде бавалы қаваздармен басқару тәжірибесі талданды.

Зерттеу нәтижелері. Нәтижесінде алынган зерттеулер республикалық және өцірлік деңгейде кеңістіктік дамуды мемлекеттік басқарудың қаржы саясатын әзірлеу кезінде де, сондай-ақ муниципалдық басқару денгейінде Қазақстандавы инвестичиялық прочесті жандандыру бойынша одан әрі зерттеулер жүргізу кезінде де пайдалы болуы мүмкін.

Түйін сөздер: муничипалды облигачиялар, Инфрақұрылым, жобалар, белсендіру, басқару 


\title{
МУНИЦИПАЛЬНЫЙ ИНФРАСТРУКТУРНЫЙ ПРОЕКТ В РАЗВИТИИ ИНФРАСТРУКТУРЫ
}

\author{
КАЗАХСТАНА \\ И.Ю. Хан ${ }^{1}$, А.Б.Әбілқасым², А.Ж.Курмантаева ${ }^{3}$, А.Р. Шалбаева ${ }^{4}$

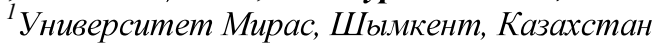 \\ ${ }^{2}$ Шымкентский университет, Шымкент, Казахстан \\ ${ }^{3}$ КазНПУ им. Абая, Алматы, Казахстан \\ ${ }^{4}$ Международный гуманитарно-технический университет, Шымкент, Казахстан \\ e-mail: musik711@mail.ru
}

Резюме. Исследование посвящено вопросам финансирования инфраструктурных проектов с использованием мунииипальных облигаиий.

Оригинальность исследования. В статье рассмотрен комплекс мер, призванных активизировать прочесс привлечения инвестиџий в инфраструктуру на уровне муниџипалитетов с использованием облигаиий. Были изучены параметры выпусков ченных бумаг кончессионеров, проанализирован опыт управления мунииипальных образований с ченными бумагами как элементом долговой политики.

Результаты исследования. Полученные в результате исследования, могут быть полезны как при разработке финансовой политики государственного управления пространственным развитием на республиканском и региональном уровне, так и при проведении дальнейших исследований по активизаиии инвестииионного прочесса в Казахстане на уровне муниџипального управления.

Ключевые слова: муниципальные облигаиии, инфраструктура, проекты, активизаиия, управление.

\section{IRSTI 06.73}

UDC 338.012

https://doi.org/10.51579/1563-2415.2021-1.21

\section{AGRO-INDUSTRIAL COMPLEX: ACTIVATION AND ASSESSMENT OF KAZAKHSTAN'S ADAPTABILITY WITHIN THE FRAMEWORK OF THE EURASIAN ECONOMIC UNION}

\author{
A. D. Umbitaliev ${ }^{* 1}$, B. N. Sabenova ${ }^{2}$, T. N. Mashirova ${ }^{3}$ \\ ${ }^{I}$ Shymkent University, Shymkent, Kazakhstan \\ ${ }^{2,3}$ NJC South Kazakhstan state university named after M. Auezov, Shymkent, Kazakhstan \\ e-mail: akmira777@mail.ru
}

Annotation. The research is devoted to the issues of adaptability, agro-industrial complex, Kazakhstan, within the framework of the Eurasian economic Union and increasing its competitiveness.

Originality of the research. The authors believe that the assessment of the competitiveness of the agroindustrial complex should be carried out not by absolute, but by relative indicators: crop yield, productivity of livestock and poultry, net export index, profitability of production, the degree of depreciation of fixed assets, the volume of products per capita. Based on the analysis, the authors concluded that each partner country in the EAEU has its own comparative advantages, which should be taken into account when forming a single food market within the framework of the Eurasian economic Union.

Research result. The article examines the impact of economic integration on the national economy, including the country's agro-industrial complex. Positive and negative effects of integration are revealed. The dynamics of economic indicators of agriculture in Kazakhstan, Russia and Belarus is analyzed.

Key words: agro-industrial complex, economic adaptation, efficiency, competitiveness.

Basic provisions. The directions of using the best foreign practices of ensuring the competitiveness of the agro-industrial complex in relation to the Russian conditions and the task of adapting the Kazakh agro-industrial complex to the requirements of the Eurasian Economic Union are determined: 1) identification of fundamental differences in the institutional environment of the functioning of agro-industrial complexes in the leading agricultural states and in Kazakhstan; 2) identify key areas of application of foreign experience of state support of agro-industrial complex (coordination of national policies to support agriculture in the framework of integration associations, special-purpose regulation, tariff and non-tariff restrictions on imports of agricultural products, support the incomes of producers of agricultural products.

Introduction. Interstate economic integration is a characteristic feature of the current stage of development of the world economy (there are currently 21 integration groupings in the world) and has become a powerful tool for accelerated development of regional economies, increasing the competitiveness of countries that are members of integration associations on the world market. 